\title{
Sociobiology
}

RESEARCH ARTICLE - BEES

\section{Nesting stingless bees in urban areas: a reevaluation after eight years}

\author{
KM Vieira, P Netto, Dlas Amaral, SS Mendes, lC CAstro, F Prezoto \\ Universidade Federal de Juiz de Fora, Juiz de Fora- MG, Brazil
}

\section{Article History}

\section{Edited by}

Candida M. L. Aguiar, UEFS, Brazil

Received

11 March 2015

Initial acceptance 21 September 2015

Final acceptance $\quad 01$ July 2016

Publication date 25 October 2016

\section{Keywords}

Urban expansion, hollow trees, urban sprawl, richness, diversity.

\section{Corresponding author \\ Fabio Prezoto \\ Universidade Federal de Juiz de Fora \\ LABEC - Campus Universitário \\ Rua José Lourenço Kelmer, $\mathrm{s} / \mathrm{n}$ \\ São Pedro - CEP: 36036-900 \\ Juiz de Fora- MG, Brasil \\ E-Mail: fabio.prezoto@ufjf.edu.br}

\begin{abstract}
Studies of nesting ecology have proven to be extremely important for stingless bee conservation. These studies have rarely been conducted in urban landscapes, and even fewer have compared species diversity and abundances over time. We surveyed native stingless bee nests at the Federal University of Juiz de Fora campus in Minas Gerais, southeastern Brazil, from May 2008 to April 2009. We recorded the number of nests, nest height, species diversity, and nest substrate type (i.e., natural or artificial). We compared our results to those of a similar survey carried out in the same location eight years prior (2000/2001) in order to evaluate how urban expansion on campus has influenced the Meliponini bee community. Stingless bee abundance and richness were greater in the second survey. The use of natural substrates decreased, while the use of artificial substrates increased. This suggests that the increase in man-made structures on the UFJF campus has provided favorable sites for establishment of some stingless bee species.
\end{abstract}

\section{Introduction}

Stingless bees (Apidae, Meliponini) are eusocial species with populous colonies varying from hundreds to thousands of individuals (Michener, 1974; Nogueira-Neto, 1997). Brazil contains roughly 244 valid species and 89 undescribed forms across 29 genera (Pedro, 2014). As the majority of species feed on nectar and pollen, they play a key role in the pollination of many native plants and cultivated plants from tropical environments, and together represent one of the largest groups of visitors to flowering plants in the tropics. (Kerr et al., 1996; Heard, 1999; Cruz et al., 2005).

Stingless bees can be found in urban environments if favorable conditions for survival exist. Some stingless bees, such as Nannotrigona testaceicornis (Lepeletier) and Tetragonisca angustula (Latreille), adapt very well to urban conditions and are common in southeastern Brazilian cities (Pirani \& Cortopassi-Laurino, 1994; Batista et al., 2003;
Souza et al., 2005; Zanette et al., 2005). Some species are even found nesting in rock crevices and man-made structures (Velthuis, 1997). Their ability to succeed in urban environments depends on several factors, including food availability (e.g., nectar, pollen, and water), nesting site availability (e.g., mud, oil, resin), and intrinsic factors related to the geographic distribution of each species (Batista et al., 2003; Samejima et al., 2004; Souza et al., 2005; Antonini et al., 2012). Stingless bees usually build cryptic nests that may remain at the same site for many years. However, sometimes they build exposed nests (as in Trigona spinipes) (Almeida \& Laroca, 1988) or occupy pre-existing cavities such as tree hollows, holes in the ground, or abandoned termite, ant, or bird nests (NogueiraNeto, 1997, Silveira et al., 2002). Loss or alteration of nesting substrate may result in increased populations of some species and local extinctions of others, where the responses are driven by species differences in foraging and nesting habits (Cane, 2001; Antonini et al., 2012). 
Studies in urban areas are critical for gaining ecological information (e.g., species diversity, resource interactions, nest density, among others) to inform strategies for species management and conservation. A survey of stingless bee nests was conducted in 2000/2001 on the Campus of the Federal University of Juiz de Fora (Sousa et al., 2002). The present study assessed variation in stingless bee nesting habits eight years after the initial survey, and addressed the following questions: 1) How does stingless bee diversity and abundance change in urban environments after area expansion? And 2) How do these variables correlate with nesting substrate type and availability?

\section{Material and methods}

The study took place at the Federal University of Juiz de Fora (UFJF) campus, Juiz de Fora, Minas Gerais, southeastern Brazil (21 ${ }^{\circ} 46^{\prime} \mathrm{S}$ and $43^{\circ} 21^{\prime} \mathrm{W}, 800 \mathrm{~m}$ a.s.l.). The UFJF campus has a total area of 123.41 ha, with urban infrastructure such as buildings, paved streets, and parking lots (Infrastructure Office database at UFJF- PROINFRA/UFJF, personal communication, May, 2010). The street edges and parking lots are surrounded by Atlantic forest fragments, as well as Pinus spp. and Eucalyptus spp., and some ornamental woody species (Moreira \& Carvalho, 2013). Regional climate is classified as tropical highland (Cwa) according to the Köppen system, with a warm, rainy season from October to March and a cold, dry season from April to September.

Nest searches were carried out once per week from March to April 2008, always between 9am and 12pm (total search time $=120$ hours). Five researchers carefully checked all buildings and adjacent vegetation (gardens and flower beds only) for active colonies. Once per month from May 2008 to April 2009 (9am to 2pm), we searched for new colonies and monitored preexisting colonies ( $300 \mathrm{~h}$ total search time).

We recorded nest GPS coordinates, as well as height from the ground and substrate used. The substrates were categorized as artificial (openings and cracks in bricks, stones, or concrete) or natural (live trees, abandoned wasp nests). Five bees were collected from each nest for species identification. Voucher specimes were deposited in the Laboratory of Behavioral Ecology and Bioacoustics, UFJF.

We used the Shannon diversity index ( $\left.\mathrm{H}^{\prime}\right)$ (Ludwig \& Reynolds, 1988) to characterize changes in stingless bee community diversity between the 2000/2001 study (Sousa et al., 2002) and our data (2008/2009). This index is particularly sensitive to the number of rare species in a community. We then used the Pielou evenness index (Pielou, 1966), to analyze uniformity in abundance among species. We compared those indices using a Hutcheson t-test (1970) in BioEstat 5.3. Species accumulation curves were constructed using EstimateS 9.1.0 software (Colwell, 2005) to verify that the sampling effort in both surveys was sufficient to have sampled most species that were detectable using the adopted methodology. Data on the extent of urban construction vs. natural areas between surveys were provided by the PROINFRA/UFJF.

The UFJF campus was divided into ten main areas for statistical analyses. The spatial distributions of the most common species in the study were calculated using a dispersion index: DI $=\sigma / \mu$ (Clapham, 1936), where " $\sigma$ " is the sample variance and " $\mu$ " is the sample mean. A dispersion index value lower than one indicates nests that were distributed more or less evenly, a value equal to one indicates random distribution, and a value greater than one indicates aggregated distribution.

\section{Results and discussion}

We recorded 69 stingless bee colonies belonging to seven genera, with seven species (Table 1). Nest density was 1.92 nests/ha. The Shannon and Pielou index scores were 0.628 and 0.74 , respectively. Species abundances were ordered as follows: N. testaceicornis $(50.72 \%$ of all nests); T. angustula (17.4\%); Trigona spinipes (Fabricius) (13.4\%); Partamona helleri (Friese) (10.15\%); Scaptotrigona sp (4.34\%); Tetragona clavipes (Fabricius) (2.9\%); and Melipona quadrifasciata (Lepeletier) (a single nest, 1.45\%) (Table 1). In another study by Kerr et al. (1996), N. testaceicornis and T. angustula were also found to be dominant in urban environments, and the authors suggested that these species typically make nests in pre-existing cavities in human structures, soil, or hollow trees. The UFJF campus has many buildings with wall crevices that are suitable for use as nesting sites.

Artificial substrate $(\mathrm{n}=50)$ was used more frequently than natural substrate $(n=19)$, however the number of species using natural substrate was higher (7 species in natural vs. 3 in artificial) (Table 1). The higher frequency of nests in artificial substrates may be due to greater availability, as the urban area on campus is approximately 38.31 times larger than the natural area (e.g., gardens, flower beds, forest fragments). Further, the dominant species in this study ( $N$. testaceicornis and $T$. angustula) have small colonies which allows them to occupy smaller spaces, perhaps allowing them to exploit the high availability of artificial cavities (Lindauer \& Kerr, 1960; Taura \& Laroca, 1991).

$N$. testaceicornis and $T$. angustula nests were the most abundant in the former and current surveys (Table 3), and artificial substrate was used more commonly in both studies. In the 2000/2001 survey, N. testaceicornis utilized artificial substrates for $88.65 \%$ of its nests; in the current survey that proportion increased to $94 \%$. In the current study, T. angustula placed $92 \%$ of nests on buildings. Although they also exhibited a preference for buildings in the previous survey $(37.2 \%)$, they also used a variety of natural substrates at that time including trees, termite nests, and ground cavities.

Scaptotrigona sp., T. clavipes, and M. quadrifasciata nested exclusively in live trees. These species are dependent on tree hollows to nest, so the quantity of this substrate type is a limiting factor for these populations (Oliveira et al., 1995; 
Table 1: Number of nests $(\mathrm{N})$, relative frequency, height $(\mathrm{m})$ from the ground to the nest entrance, and substrates used for nesting by stingless bees in the campus of the Federal University of Juiz de Fora, southeastern Brazil.

Substrate

\begin{tabular}{|c|c|c|c|c|c|}
\hline Species observed & $\mathbf{N}$ & $\begin{array}{c}\text { Relative } \\
\text { Frequency }(\%)\end{array}$ & Height (m) & Artificial & Natural \\
\hline Melipona quadrifasciata & 01 & 1.45 & 03 & 0 & $01(100 \%)$ \\
\hline Nannotrigona testaceicornis & 35 & 50.72 & $1.11( \pm 1.66)$ & $33(94 \%)$ & $02(6 \%)$ \\
\hline Tetragonisca angustula & 12 & 17.4 & $2.88( \pm 1.77)$ & $11(92 \%)$ & $01(8 \%)$ \\
\hline Trigona spinipes & 09 & 13.04 & $11.86( \pm 4.68)$ & 0 & $09(100 \%)$ \\
\hline Partamona helleri & 07 & 10.15 & $4.97( \pm 1.47)$ & $6(86 \%)$ & $01(14 \%)$ \\
\hline Scaptotrigona sp. & 03 & 4.34 & $0.82( \pm 1.19)$ & 0 & $03(100 \%)$ \\
\hline Tetragona clavipes & 02 & 2.9 & $1.97( \pm 1.16)$ & 0 & $02(100 \%)$ \\
\hline Total & 69 & 100 & & & \\
\hline
\end{tabular}

Silveira et al., 2002; Antonini \& Martins, 2003; Werneck \& Faria-Mucci, 2014). We conclude that the presence of these species in urban environments (as in the current study) is only possible when adequate vegetation exists where they can construct nests.

Majority of Partamona species nest above ground in natural environments, where they often build nests in abandoned termite nests (Camargo, 1980; Nogueira-Neto, 1997). In this study $P$. helleri nests were found in artificial substrate, and one colony was found in an abandoned wasp nest. The occupation of abandoned nests is a simple and efficient method because it is less costly in terms of time expenditure and effort (Pinto, 2005).

Nest height in natural substrate was more variable than in artificial substrate. Nests in natural substrate were frequently found at heights up to $14 \mathrm{~m}$, where $47.36 \%$ belonged to T. spinipes. Souza et al. (2005) and Aidar et al. (2013) also found a preference for high nest placement in this species, and Wille and Michener (1973) noted that nests of this species are found a minimum of four meters above the ground. Nests in artificial substrates were found within $2 \mathrm{~m}$ above ground and height was less variable, probably because most nests $(88 \%)$ were from only two species, $N$. testaceicornis and T. angustula. These species made use of low-lying building features such as stairs, windows, and cracks in the walls as nesting substrates.

The spatial distribution index (DI) indicated the most abundant species $N$. testaceicornis and T. angustula had an aggregated distribution, with DI values of 1.2 and 2.62, respectively. $T$. spinipes nests were regularly distributed $(\mathrm{DI}<=$ $1(0.84))$. Similar distribution patterns for this species were also found Pirani and Cortopassi-Laurino, (1994) in another Brazilian urban area. Hubbel and Johnson (1977) argue that the spacing between nests is mediated by aggressive encounters between colonies competing for new nesting sites. Our results generally agree with this hypothesis because nests were closer for $N$. testaceicornis and T. angustula, which are smaller and less aggressive species. The spatial distribution of nests is also correlated with the distribution of nesting substrates, and species characteristics such as the typical distance searched to found a new nest (Hubbel \& Johnson, 1977; Serra et al., 2009). N. testaceicornis and T. angustula preferred nesting in artificial substrate such as cracks in the walls. To take advantage of the availability of such sites, their nests were necessarily spatially close. $P$. helleri also preferred artificial substrates ( $86 \%$ of nests) but is a more aggressive species that defends its territory during foraging. This probably contributed to the greater distances found between their nests. The DI value for this species was only slightly greater than 1 , indicating a distribution pattern close to even distributed (not aggregated). It was not possible to determine distribution patterns of other species due to the low sample numbers.

The UFJF campus had a low nest density ( 0.52 nests/ha) compared to other surveys in urban areas (Adair et al., 2013, 2.17 nests/ha; Taura \& Laroca, 1991, 4.91 nests/ha) (Table 2). These studies found most nests in trees, however in the present study many areas with trees were not accessible for searching. This may explain the low density of tree nests found. Despite having lower nest density, we had higher species richness than other similar studies (see Adair et al., 2013, Taura \& Laroca, 1991, Souza et al., 2005). This may have happened because although the campus is an urban site, it contains trees for the species that rely upon them (T. clavipes, $T$. spinipes, $M$. quadrifasciata) in addition to artificial substrates primarily used by $N$. testaceicornis, T. angustula, and P. helleri.

Nest abundance increased from 46 to 69 between the 2000/2001 (Sousa et al., 2002) and 2008/2009 (the current survey) (50\% increased), and species richness increased by $75 \%$ (from 4 to 7 species). Diversity (E') and evenness (J') were significantly higher in the current study (Table 3 ). All species found in both surveys (Table 3) were more abundant in the 2008-2009 survey. T. clavipes, M. quadrifasciata, and Scaptotrigona sp. were only found in the 2008/2009 survey (Table 3). Rarefaction curve showed asymptotic tendency, which indicates that the sampling effort was sufficient to compare species numbers (Figure 1). 
Table 2. Comparison of nesting attributes of stingless bees in the campus of the Federal University of Juiz de Fora and other studies in urban landscapes.

\begin{tabular}{llcccc}
\hline Study & Study area & Size of sampled area (ha) & N & Number of nests/ha & Richness \\
\hline Present study & Juiz de Fora/MG & 132.6 & 69 & 0.52 & 07 \\
Aidar et al. (2013) & Uberlândia/MG & 23 & 50 & 2.17 & 07 \\
Souza et al. (2005) & Salvador/BA & 57 & 94 & 1.64 & 05 \\
Taura \& Laroca (1991) & Curitiba/PR & 5.7 & 28 & 4.91 & 05 \\
\hline
\end{tabular}

Eight years after the study by Sousa et al. (2002) we found an increase of $7.94 \%\left(8,458.65 \mathrm{~m}^{2}\right)$ in the constructed area of the UFJF campus and a $7.36 \%\left(7,840.76 \mathrm{~m}^{2}\right)$ decrease in natural area. Although there are some differences in sampling effort between the two studies (see Materials and Methods), the 2008/2009 survey showed a significant increase in species richness and nest abundance. Martins et al. (2013) assessed the effects of urbanization in the past 40 years in an area of natural vegetation surrounded by urban or agricultural areas and found decreased bee diversity, including the loss of some species. The primarily occurred because intense urbanization deteriorated the bee foraging matrix. Taura and Laroca (2001) grouped data from surveys conducted in 1975, 1986/1987, and 1992/1993 in a green area located in downtown Curitiba, Paraná, Brazil. They concluded that the urban sprawl was linked to pollution and tree removal, which led to a significant reduction in bee species richness and abundance. Contrary to this expectation, urban expansion on the UFJF campus did not negatively affect stingless bee nest abundance or species richness. This may be due to the increase in nesting site availability for species that easily adapt to urban environments and that utilize artificial substrate, such as $T$. angustula, $N$. testaceicornis and P. helleri. Further, some species that exclusively use trees were able to do so despite expansion of the urban area of the UFJF campus.

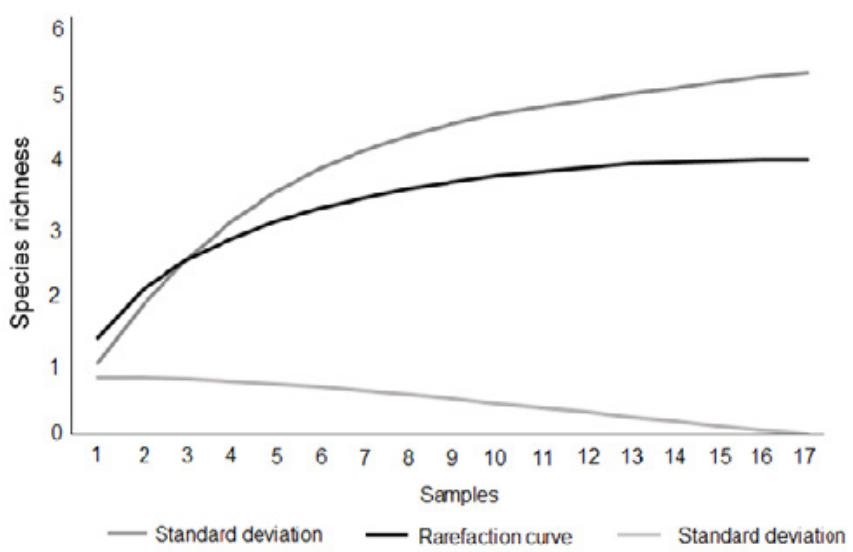

Fig 1. Rarefaction curve and standard deviation of the estimated richness in the 2008/2009 study in the campus of the Federal University of Juiz de Fora, southeastern Brazil.
We conclude that species preferences for natural or artificial substrate were relatively stable over time. Species that easily adapt to changing environments and with flexibility in use of nesting substrate ( $T$. angustula, $N$. testaceicornis and $P$. helleri) were not jeopardized by urban expansion. Tree-nesting species exclusive to the 2008/2009 survey (Scaptotrigona sp., T. clavipes, and M. quadrifasciata) were able to find habitat despite the great extent of urban area on campus. Hence, maintenance of natural areas is important for population growth and conservation of stingless bee species on this urban area.

Table 3. Comparison of nesting attributes of stingless bees in the campus of the Federal University of Juiz de Fora, southeastern Brazil, between 2000/2001 and 2008/2009.

\begin{tabular}{lll}
\hline Attributes & $\mathbf{2 0 0 0 / 2 0 0 1}$ & $\mathbf{2 0 0 8 / 2 0 0 9}$ \\
\hline Total number of colonies & 46 & 69 \\
Nannotrigona testaceicornis nests & $63.93 \%$ & $50.72 \%$ \\
Tetragonisca angustula nests & $24.46 \%$ & $17.4 \%$ \\
Trigona spinipes nests & $6.74 \%$ & $13.04 \%$ \\
Partamona helleri nests & $4.87 \%$ & $10.15 \%$ \\
Scaptotrigona sp. nests & 0 & $4.34 \%$ \\
Tetragona clavipes nests & 0 & $2.9 \%$ \\
Melipona quadrifasciata nests & 0 & $1.45 \%$ \\
Total density & 3.84 nests $/ \mathrm{ha}$ & $5.37 \mathrm{nests} / \mathrm{ha}$ \\
Total richness & 4 & 7 \\
Number of nests in artificial substrates & 27 & 50 \\
Number of nests in natural substrates & 19 & 8 \\
Constructed area in the campus & 11.6 ha & $12.52 \mathrm{ha}$ \\
Natural area in the campus & 0.35 ha & $0.32 \mathrm{ha}$ \\
Diversity index (H') & 0.42 & 0.62 \\
Evenness Index (J') & 0.69 & 0.74 \\
\hline Diversity in 2001/2002 X Diversity in $2008 / 2009$ & $\mathrm{t}=9.1062 ; \mathrm{df}=11 ; \mathrm{p}$ \\
$<0.0001$ & & \\
Abundance in 2001/2002 X Abundance in $2008 / 2009$ & $\mathrm{t}=5.8033 ; \mathrm{df}=22 ;$ \\
p <0.0001 & & \\
(t): Hutcheson t test; (df): degrees of freedom & \\
\hline
\end{tabular}

\section{Acknowledgements}

We would like to thank CNPq for the financial support, Dr. Georgina Maria de Faria Mucci for species identification and Erick Esteves for collaboration in the components of field and laboratory. 


\section{References}

Aidar, I. F., Santos, A. O. R., Bartelli, B. F., Martins, G. A., Nogueira-Ferreira, F. H. (2013). Nesting ecology of stingless bees (Hymenoptera, Meliponina) in urban areas: The importance of afforestation. Bioscience Journal, 29: 13601368. doi: $10.5061 /$ dryad.k54hk

Almeida, M. C. \& S. Laroca. (1988). Trigona spinipes (Apidae, Meliponinae): Taxonomia, bionomia e relações tróficas em áreas restritas. Acta Biológica Paranaense, Curitiba, 17: 67-108.

Antonini, Y. \& Martins, R. P. (2003). The value of a tree species (Caryocar brasiliense) for a stingless bee Melipona quadrifasciata quadrifasciata. Journal of Insect Conservation, 7(3), 167-174.

Antonini, Y., Martins, R. P., Aguiar, L. M. \& Loyola, R. D. (2012). Richness, composition and trophic niche of stingless bee assemblage in urban forest remnants. Urban Ecosystems, 16: 527-541. doi: 10.1007/s11252-012-0281-0

Batista, M. A., Ramalho, M. \& Soares, A. E. E. (2003). Nesting sites and abundance 12 of Meliponini (Hymenoptera: Apidade) in heterogenous habitats of the Atlantic Rain Forest, Bahia, Brazil. Lundiana, 4: 19-23.

Camargo, J. M. F. (1980). O grupo Partamona (Partamona) testacea (Klung): suas espécies, distribuição e diferenciação geográfica (Meliponinae, Apidae, Hymenoptera). Acta Amazônica, 10:1-175.

Cane, J. H. (2001). Habitat fragmentation and native bees: a premature verdict? Conservation Ecology, 5: 3.

Clapham, A. R. (1936). Over dispersion in grassland communities and the use of statistical methods in plant ecology. Journal of Ecology, 24: 232-251.

Colwell, R. K. (2005). Estimates: Statistical estimation of species richness and shared species from samples. Version 7.5. User's Guide and application published at: http://purl. oclc.org/estimates

Cruz, D. D. O., Freitas, B. M., Silva, L. A. D., Silva, E. M. S. D., \& Bomfim, I. G. A. (2005). Pollination efficiency of the stingless bee Melipona subnitida on greenhouse sweet pepper. Pesquisa Agropecuária Brasileira, 40: 1197-120. doi: 10.1590/ S0100-204X2005001200006

Heard, T. A. (1999). The role of stingless bees in crop pollination. Annual Review of Entomology, 44: 183-206.

Hubbel, S. P. \& Johnson, L K. (1977). Competition and nest spacing in a tropical stingless bee community. Ecology, 58: 949-963.

Hutcheson, K. (1970). A test for comparing diversities based on the Shannon formula. Journal of Theoretical Biology, 29: 151-154. doi: 10.1016/0022-5193(70)90124-4
Pielou, E. C. (1966). The measurement of diversity in different types of biological collections. Journal of Theoretical Biology, 13: 131-144. doi: 10.1016/0022-5193(66)90013-0

Kerr, W. E., Carvalho, G. A. \& Nascimento, V. A. (1996). Abelha Uruçu. Biologia, Manejo e Conservação. Coleção Manejo da Vida Silvestre, v. 2. Fundação Acangaú, Belo Horizonte, 143 p.

Lindauer, M. \& Kerr, W. E. (1960). Communication between the workers of stingless bees. Bee world, 41: 29-41.

Ludwig, J. A. \& Reynolds, J. F. (1988). Statistical ecology: a primer in methods and computing (Vol. 1). John Wiley \& Sons.

Martins, A. C., Gonçalves, R. B. \& Melo, G. A. R. (2013). Changes in wild bee fauna of a grassland in Brazil reveal negative effects associated with growing urbanization during the last 40 years. Zoologia, 30: 157-176. doi: 10.1590/S198446702013000200006

Michener, C. D. (1974). The Social Behavior of the Bees: a comparative study. Harvard University Press, Cambridge, Massachusetts, 404 pp. doi: 10.1007/BF02223852

Moreira, B. \& Carvalho, F. A. (2013). A comunidade arbórea de um fragmento urbano de Floresta Atlântica após 40 anos de sucessão secundária (Juiz de Fora, Minas Gerais). Biotemas, 26: 59-70. doi: 10.5007/2175- 7925.2013v26n2p5

Nogueira-Neto, P. (1997). Vida e Criação de Abelhas Indígenas Sem Ferrão. São Paulo: Nogueirapis, 445 p.

Oliveira, M. L.; Morato, E. F. \& Garcia, M.V. B. (1995). Diversidade de espécies e densidade de ninhos de abelhas sociais sem ferrão (Hymenoptera, Apidae, Meliponinae) em floresta de terra firme na Amazônia Central, Neotropical Entomology, 12: 13-24. doi: 10.1590/S0101-817519950 00100004

Pedro, S. R. (2014). The stingless bee fauna in Brazil (Hymenoptera: Apidae). Sociobiology, 61: 348-354. doi: 10.13102/sociobiology.v61i4.348-35

Pinto, N. P. O. (2005). Estudo de caso: a reutilização de células de ninho abandonado de Polistes (Aphanilopterus) simillimus Zikán, 1951 (Hymenoptera: Vespidae, Polistinae) por Tetrapedia (Tetrapedia) diversipes Klug, 1810 (Hymenoptera: Apidae, Apinae). Revista de Etologia, 7: 67-74.

Pirani, J. R. \& Cortopassi-Laurino, M. (1994). Flores e abelhas em São Paulo. 2 ed. São Paulo, EDUSP/FAPESP, 192p.

Samejima, H., Marzuki, M., Nagamitsu, T., \& Nakasizuka, T. (2004). The effects of human disturbance on a stingless bee community in a tropical rainforest. Biological Conservation, 120: 577-587. doi: 10.1016/j.biocon.2004.03.030

Serra, B. D., Drummond, M. S., Lacerda, L. D. M. \& Akatsu, I. P. (2009). Abundância, distribuição espacial de ninhos de abelhas Meliponina (Hymenoptera, Apidae, Apini) e espécies vegetais utilizadas para nidificação em áreas de cerrado do 
Maranhão.Iheringia. Série Zoologia, 99: 12-17. doi: 10.15 90/ S0073-47212009000100002

Silveira, F. A.; Melo, G. A. \& Almeida, E. A. (2002). Abelhas brasileiras. Sistemática e Identificação. Fundação Araucária, Belo Horizonte, 253 p.

Sousa, L. A., Pereira, T. O., Prezoto, F. \& Faria Mucci, G. M. (2002). Nest foundation and diversity of Meliponini (Hymenoptera, Apidae) in an urban area of the municipality of Juiz de Fora, MG, Brasil. BioScience Journal, 18: 59-65. doi: 10.5061/dryad.k54hk

Souza, S. G. X.; Teixeira, A. F. R.; Neves, E. L.; Melo, A. M. C. (2005). As abelhas sem ferrão (Apidae: Meliponina) residentes no campus Federação/Ondina da Universidade Federal da Bahia, Salvador, Bahia, Brasil. Candombá. Revista Virtual, 1: 57-69.

Taura H. M. \& Laroca, S. (1991). Abelhas altamente sociais (Apidae) de uma área restrita em Curitiba (Brasil): Distribuição dos ninhos e abundância relativa. Acta Biológica Paranaense, 20: 85-101. doi: 10.5380/abpr.v20i0.764.
Taura, H. M., \& Laroca, S. (2001). A associação de abelhas silvestres de um biótopo urbano de Curitiba (Brasil), com comparações espaço-temporais: abundância relativa, fenologia, diversidade e explotação de recursos (Hymenoptera, Apoidea). Acta Biológica Paranaense, 30: 2.

Velthuis, H. H. W. Biologia das abelhas sem ferrão. (1997). São Paulo: Edusp, 33 p.

Werneck, H. A., \& Faria-Mucci, G. M. (2014). Abelhas sem ferrão(Hymenoptera:Apidae:Meliponini) da EstaçãoEcológica de Água Limpa, Cataguases-MG, Brasil. EntomoBrasilis, 7: 164-166. doi: 10.12741

Wille, A. \& Michener, C. D (1973). The nest architecture of stingless bess with special reference to those of Costa Rica (Hymenoptera: Apidae). Revista de Biologia Tropical, 21: 1278.

Zanette, L. R. S., Martins, R. P., \& Ribeiro, S. P. (2005). Effects of urbanization on Neotropical wasp and bee assemblages in a Brazilian metropolis. Landscape and Urban Planning, 71, 105-12. doi: 10.1016/j.landurbplan.2004.02.003 